\title{
Situation of breastfeeding and complementary feeding in a medium-sized municipality in the Ribeira Valley, São Paulo
}

\author{
Situação da amamentação e alimentação complementar \\ em um município de médio porte \\ do Vale do Ribeira, São Paulo
}

Gislene dos Anjos TAMASIA 1

Sonia Isoyama VENÂNCIO²

Silvia Regina Dias Medici SALDIVA ${ }^{3}$

A B S T R A C T

\section{Objective}

To analyze the situation of breastfeeding and complementary feeding in the city of Registro, São Paulo.

\section{Methods}

This cross-sectional study collected sociodemographic and feeding information of infants aged less than one year who participated in the 2011 multiple vaccine campaign. Breastfeeding and complementary feeding were analyzed by indicators proposed by the World Health Organization. The association between outcomes (exclusive breastfeeding and introduction to complementary feeding) and the explanatory variables (maternal and child characteristics) was investigated by the Poisson model with a robust error variance.

\section{Results}

We analyzed 713 children. The prevalence of exclusive breastfeeding was $50.0 \%$. Children who were breastfed exclusively on the first day at home $(P R=2.40 ; 95 \% \mathrm{Cl}=1.42-4.06)$ and not given pacifiers $(P R=1.95 ; 95 \% \mathrm{Cl}=1.15-$ 3.30) were more likely to be exclusively breastfed. The complementary feeding indicators showed that $62.1 \%$ of the children aged 6 to 8.9 months consumed fruit plus savory mashes. None of the explanatory variables was significantly associated with this outcome.

1 Faculdades Integradas do Vale do Ribeira, Curso de Nutrição, Departamento de Nutrição. R. Oscar Yoshiaki Magário, 185, Jd. das Palmeiras, 11900-000, Registro, SP, Brasil. Correspondência para/Correspondence to: GA TAMASIA. E-mail: <gisleneanjos@usp.br>.

2 Instituto de Saúde, Centro de Tecnologias em Saúde. São Paulo, SP, Brasil.

${ }^{3}$ Instituto de Saúde, Centro de Pesquisa e Desenvolvimento. São Paulo, SP, Brasil.

Article based on the master's thesis of GA TAMASIA, intitled: "Perfil da amamentação e alimentação complementar no município de Registro-SP". Universidade de São Paulo; 2013. 


\section{Conclusion}

The study identified inappropriate infant feeding practices. Such studies can contribute to the proposal of policies, which is particularly important in an unfavorable social development context characterized by the study city.

Keywords: Breast feeding. Indicators. Supplementary feeding.

\section{R E S U M O}

\section{Objetivo}

Analisar a situação da amamentação e alimentação complementar no município de Registro, São Paulo.

\section{Métodos}

Estudo transversal no qual foram coletadas informações sobre alimentação e dados sociodemográficos de crianças menores de um ano que participaram da campanha de multivacinação de 2011. Foram consideradas elegíveis todas as crianças menores de um ano que participaram da campanha de vacinação, a fim de garantir a representatividade das informações para o município. Realizou-se a análise dos indicadores de aleitamento materno e alimentação complementar, propostos pela Organização Mundial de Saúde. A associação entre os desfechos (aleitamento materno exclusivo e introdução da alimentação complementar) e as variáveis explanatórias (características maternas e infantis), realizou-se por meio do modelo de regressão de Poisson com variância robusta.

\section{Resultados}

Foram analisados dados de 713 crianças. A prevalência do aleitamento materno exclusivo de 0 a 6 meses foi de $50,0 \%$. As crianças que estavam mamando exclusivamente no primeiro dia em casa $(R P=2,40 ; I C 95 \%=1,42-$ $4,06)$ e não usavam chupeta $(R P=1,95 ; I C 95 \%=1,15-3,30)$ foram as que apresentaram maior chance de aleitamento materno exclusivo. Ao analisar os indicadores de alimentação complementar, observou-se que a proporção de crianças de 6 a 8,9 meses que consumiram fruta mais papa salgada foi de 62,1\%. Nenhuma das variáveis explanatórias mostrou associação significativa com esse desfecho.

\section{Conclusão}

O estudo identificou práticas de alimentação infantil inadequadas. A realização de estudos desse tipo pode contribuir para a formulação de propostas de intervenção, o que se torna particularmente relevante em um contexto de desenvolvimento social pouco favorável, como o que caracteriza o município estudado.

Palavras-chave: Aleitamento materno. Indicadores. Suplementação alimentar.

\section{INTRODUCTION}

Breastfeeding has unquestionable advantages for the child and the mother. It is an important strategy for promoting the mother-child bond, and protecting and nourishing the child. It is a sensitive, inexpensive, and effective intervention to reduce infant morbidity and mortality, and promotes the holistic health of the mother-child dyad ${ }^{1}$. The World Health Organization (WHO) and the Brazilian Ministry of Health $(\mathrm{BMH})$ recommend exclusive breastfeeding until age six months, and after this age, infants should receive complementary foods in addition to breast milk until age two years or later ${ }^{2}$. For breastfeeding promotion to be successful, engagement of the public authorities is essential. In this sense, the Sistema Único de Saúde (SUS, Unefied Healh Care System) has recorded initiatives at different levels to reduce infant mortality and encourage breastfeeding. However, Brazil is still far from reaching the target recommended by the $\mathrm{WHO}^{3}$.

The advantages of exclusive breastfeeding are acknowledged, but from age six months, the nutritional needs of infants cannot be met by breast milk alone. Promoting the nutritional adequacy of complementary foods in this phase is a determinant in the prevention of childhood morbidity and mortality ${ }^{4}$. However, achieving an 
appropriate diet for the children should be an essential component of the global strategy to assure the food security of a population. The final success of promoting complementary feeding depends on appropriate governmental policies and the support and participation of the entire society. Nonetheless, health professionals have an essential role in this promotion and can influence appropriate practices when complementary foods are introduced ${ }^{5}$.

The World Health Organization recommends that complementary foods be introduced at age six months in small amounts, increasing gradually as the child grows. From this age onward, the child already has physiological and neurological maturity to consume other foods. Nevertheless, it is important for the child to continue breastfeeding until age two years or more, given that breast milk is nutritious and protects the child from diseases ${ }^{6}$.

Analysis of infant feeding practices is particularly important in not very favorable social development contexts because of its ability to reduce infant morbidity and mortality. Registro is a medium-sized municipality in the state of São Paulo whose Human Development Index (HDI) ranked 199 among the 645 state municipalities in 2010. The municipality is characterized by low income, longevity, and education indices ${ }^{7}$. Hence, the objective of this study is to analyze the situation of breastfeeding and complementary feeding in Registro (SP), in 2011.

\section{METHODS}

This analytical, cross-sectional, populationbased study was conducted during the multiple vaccine campaign of 2011 and included children aged less than one year. The study used the methodology proposed by the Projeto Amamentação e Municípios (AMAMUNIC, Project Breastfeeding and Municipalities), whose objective is to collect information about the breastfeeding and complementary feeding profiles of municipalities in the state of São Paulo ${ }^{8}$.
According to this methodology, all children aged less than one year who participated in the multiple vaccine campaign are eligible for the study, and municipalities with up to 1,500 children the year before the study should conduct the survey on all children ${ }^{8}$. Thus, the present study considered eligible all children aged less than one year who participated in the vaccination campaign to ensure the representativeness of the municipal information.

The exclusive breastfeeding categories and indicators used by the present study are based on a publication by the $\mathrm{WHO}$ that provides fifteen indicators for assessing the adequacy of the feeding practices of children aged 0 to 23 months, of which seven are optional ${ }^{9}$. The proposed exclusive breastfeeding indicators also took into account the recommendations of the Food Guide for Children aged less than two years ${ }^{10}$. Some adaptations were necessary because the study included children aged less than one year (the indicators proposed by the $\mathrm{WHO}$ include children aged up to 24 months). Furthermore, since the questionnaire was administered during the vaccination campaign, it had to be administered quickly not to interfere with the vaccination, so the intake of foods 24 hours before the interview was not investigated as thoroughly as required by the $\mathrm{WHO}$, imposing some limitations on the construction of the indicators.

The outcomes of the present study were defined as follows: exclusive breastfeeding when the child is given breast milk, oral rehydration fluids, and/or vitamin, mineral, and medication drops or syrups from ages 0 to 6 months; and correct introduction of complementary feeding when the child is given fruits and a savory mash from ages 6 to 9 months.

The study child characteristics that could possibly affect the outcomes of interest were: gender (female/male), low birth weight (yes/no), type of delivery (vaginal/caesarian), breastfed in the first hour of life (yes/no), exclusive breastfeeding on the first day at home (yes/no), use of bottle (yes/no), use of pacifier (yes/no), and 
follow-up at a health care facility (SUS or private). The mother-related explanatory variables were: age (<20; 20-35; and $>35$ years), number of parturitions (primiparous/multiparous), employment status (works away from home/does not work away from home), and education level (<8 years; $8-11$; >11 years)

The study indicators were descriptively analyzed by calculating the proportions. The median exclusive breastfeeding and breastfeeding were given by logit analysis, which uses statistical modeling to estimate the probability of the study event as a function of the child's age ${ }^{11}$. To assess the association between the explanatory variables and the outcomes, crude and adjusted analyses were done using Poisson regression with robust error variance given that this is a cross-sectional study and the outcomes are not rare ${ }^{12}$. The variables with $p<0.20$ in the simple regression were included in the multiple model. The data were analyzed by the software Stata 10.1.

The study protocol was approved on May 6, 2008, by the Research Ethics Committee of the Institute of Health under Protocol number $001 / 2008$.

\section{RES U L T S}

The population of children aged less than one year in the municipality of Registro (SP) in 2011 was 871 , and 836 were vaccinated, resulting in a vaccination coverage of $96.0 \%$. We collected data from 723 children, of which ten (1.4\%) were excluded from the analysis because their birth date was missing. The total study sample was 713 children, representing coverage of $86.5 \%$ children of the age bracket of interest. In relation to the sample, $89.4 \%$ of the children lived in urban areas, $94.5 \%$ lived in Registro (SP), and $87.7 \%$ were accompanied by their mothers.

Table 1 shows the distribution of the sample according to the children's and mothers' characteristics. Gender distribution was similar.
Most children were delivered vaginally (normally or through the use of a forceps), but the caesarian rate was high at $43.7 \%$. The proportion of exclusively breastfed children on the first day at home after hospital discharge was high, although more than half of the mothers reported using a bottle and $40.0 \%$ had used a pacifier the day before the interview. Most mothers were aged between 20 and 35 years, did not work away from home, and had 8 to 11 years of formal education.

Table 1. Distribution of the maternal and child characteristics in the study sample. Registro (SP), 2011.

\begin{tabular}{|c|c|c|}
\hline Variables & $n$ & $\%$ \\
\hline \multicolumn{3}{|l|}{ Child's gender } \\
\hline Male & 365 & 51.2 \\
\hline Female & 348 & 48.8 \\
\hline \multicolumn{3}{|l|}{ Low birth weight } \\
\hline Yes & 46 & 6.9 \\
\hline No & 620 & 93.1 \\
\hline \multicolumn{3}{|l|}{ Type of delivery } \\
\hline Vaginal & 389 & 56.2 \\
\hline Caesarian & 303 & 43.8 \\
\hline \multicolumn{3}{|l|}{ Use of artificial teats } \\
\hline Bottle & 362 & 52.3 \\
\hline Pacifier & 279 & 40.4 \\
\hline \multicolumn{3}{|c|}{ Exclusively breastfed on the first day at home } \\
\hline Yes & 185 & 81.9 \\
\hline No & 41 & 18.1 \\
\hline \multicolumn{3}{|l|}{ Follow-up } \\
\hline Unified Health Care System & 463 & 77.0 \\
\hline Private Network & 138 & 23.0 \\
\hline \multicolumn{3}{|l|}{ Mother's age } \\
\hline$<20$ years & 92 & 12.7 \\
\hline 20-35 years & 436 & 60.3 \\
\hline$>35$ years & 76 & 10.5 \\
\hline \multicolumn{3}{|l|}{ Parity } \\
\hline Primiparous & 276 & 46.2 \\
\hline Multiparous & 322 & 53.8 \\
\hline \multicolumn{3}{|l|}{ Employment status } \\
\hline Works & 113 & 18.8 \\
\hline Does not work & 487 & 81.2 \\
\hline \multicolumn{3}{|c|}{ Maternal years of formal education } \\
\hline Up to 8 years & 116 & 19.7 \\
\hline 8 to 11 years & 373 & 63.4 \\
\hline$>11$ years & 99 & 16.8 \\
\hline
\end{tabular}


Figure 1 shows the exclusive breastfeeding and breastfeeding probabilities according to the children's ages. The exclusive breastfeeding rates plummeted during the first days of life. After ninety days, the probability dropped to less than $50 \%$, and at 180 days, the probability of being exclusively breastfed was around $13 \%$. The probability of breastfeeding remained higher than $70 \%$ up to 180 days of life, dropping to $47 \%$ of the children at around age one year. The median durations of exclusive breastfeeding and breastfeeding were 79.7 days (95\% Confidence Interval-95\% $\mathrm{Cl}=67.66-90.36)$ and 350.23 days (95\% Cl=312.96-406.39), respectively.

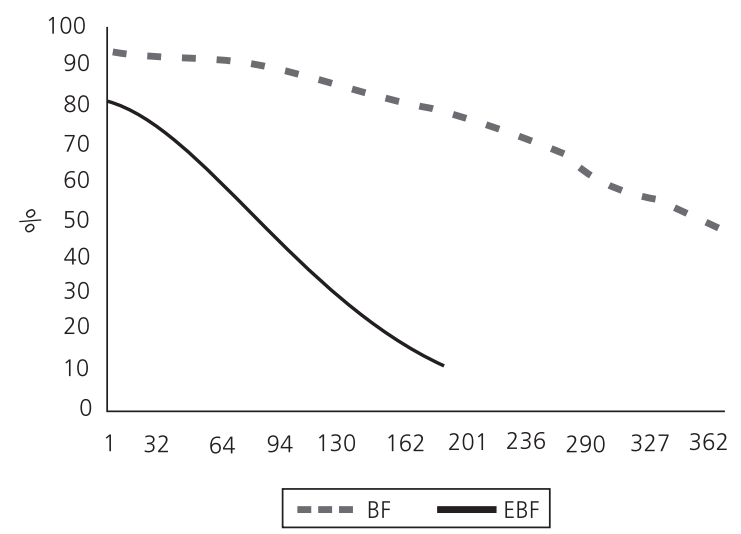

Figure 1. Probability of children aged less than one year being Exclusively Breastfed (EBF) and Breastfed (BF). Registro (SP), 2011.

Table 2. Distribution of the children according to exclusive breastfeeding and complementary feeding indicators. Registro (SP), 2011.

\begin{tabular}{|c|c|c|}
\hline Variables & $\mathrm{n}$ & $\%$ \\
\hline \multicolumn{3}{|c|}{ Breastfed in the first hour of life } \\
\hline Yes & 546 & 81.1 \\
\hline No & 127 & 18.9 \\
\hline \multicolumn{3}{|c|}{ Exclusively breastfed $<6$ months } \\
\hline Yes & 205 & 49.9 \\
\hline No & 206 & 50.1 \\
\hline \multicolumn{3}{|c|}{ Breastfed from 9-12 months } \\
\hline Yes & 76 & 59.8 \\
\hline No & 51 & 40.2 \\
\hline \multicolumn{3}{|c|}{ Children aged 6 to 8.9 months given fruits and savory meals } \\
\hline Yes & 90 & 62.1 \\
\hline No & 55 & 37.9 \\
\hline \multicolumn{3}{|c|}{ Children aged 6 to 6.9 months given 1 savory meal } \\
\hline Yes & 13 & 35.1 \\
\hline No & 24 & 64.9 \\
\hline \multicolumn{3}{|c|}{ Children aged 7 to 11.9 months given 2 savory meals } \\
\hline Yes & 123 & 66.5 \\
\hline No & 62 & 33.6 \\
\hline \multicolumn{3}{|c|}{ Children aged 8 to 11.9 months given foods prepared for the family } \\
\hline Yes & 59 & 39.6 \\
\hline No & 90 & 60.4 \\
\hline \multicolumn{3}{|c|}{ Children aged 6 to 11.9 months given high-iron foods } \\
\hline Yes & 222 & 93.7 \\
\hline No & 15 & 6.3 \\
\hline \multicolumn{3}{|c|}{ Children aged 6 to 11.9 months given at least 1 unhealthy food } \\
\hline Yes & 204 & 75.6 \\
\hline No & 66 & 24.4 \\
\hline
\end{tabular}


Table 2 shows the breastfeeding and complementary feeding indicators of the study population. Most children were breastfed in the first hour of life after delivery, half the children aged less than six months were being exclusively breastfed, and $60 \%$ continued to breastfeed at the end of the first year of life (between 9 and 12 months).

The complementary feeding indicators showed that $62.0 \%$ of the children aged 6 to 8.9 months consumed fruits and at least one savory meal, as recommended by the $\mathrm{BMH}$, and only

Table 3. Proportion of Exclusively Breastfed Children (EBF) aged less than six months and respective Prevalence Ratios (PR) and crude and adjusted 95\% Confidence Intervals $(95 \% \mathrm{Cl})$ by maternal and child characteristics. Registro (SP), 2011.

\begin{tabular}{|c|c|c|c|c|c|c|c|c|}
\hline \multirow{2}{*}{ Variables } & \multicolumn{2}{|c|}{ EBF children* } & \multicolumn{3}{|c|}{ Crude $P R$} & \multicolumn{3}{|c|}{ Adjusted $P R$} \\
\hline & $n$ & $\%$ & $P R$ & $95 \% \mathrm{Cl}$ & $p$ & $P R$ & $95 \% \mathrm{Cl}$ & $p$ \\
\hline \multicolumn{9}{|l|}{ Gender } \\
\hline Male & 213 & 46.0 & 1 & & & & & \\
\hline Female & 198 & 53.5 & 1.2 & $0.9-1.5$ & 0.28 & & & \\
\hline \multicolumn{9}{|l|}{ Low birth weight } \\
\hline Yes & 29 & 31.0 & 1 & & & 1 & & \\
\hline No & 360 & 51.9 & 1.1 & $0.9-1.3$ & 0.12 & 1.1 & $0.8-1.6$ & 0.55 \\
\hline \multicolumn{9}{|l|}{ Delivery } \\
\hline Caesarian & 173 & 50.2 & 1 & & & & & \\
\hline Vaginal & 233 & 50.3 & 1.0 & $0.8-1.3$ & 0.99 & & & \\
\hline \multicolumn{9}{|c|}{ Breastfed in the first hour of life } \\
\hline No & 78 & 41.0 & 1 & & & & & \\
\hline Yes & 317 & 51.7 & 1.2 & $0.9-1.7$ & 0.23 & & & \\
\hline \multicolumn{9}{|l|}{$E B F^{*}$ on first day at home } \\
\hline No & 39 & 25.6 & 1 & & & 1 & & \\
\hline Yes & 173 & 73.4 & 2.8 & $1.8-4.4$ & 0.00 & 2.4 & $1.4-4.1$ & 0.01 \\
\hline \multicolumn{9}{|l|}{ Pacifier } \\
\hline Yes & 160 & 33.8 & 1 & & & 1 & & \\
\hline No & 245 & 60.4 & 1.7 & $1.3-2.2$ & 0.00 & 1.9 & $1.1-3.3$ & 0.01 \\
\hline \multicolumn{9}{|l|}{ Follow-up } \\
\hline Unified Health Care System & 280 & 52.1 & 1 & & & & & \\
\hline Private network & 67 & 47.8 & 0.9 & $0.6-1.3$ & 0.64 & & & \\
\hline Maternal age & & & & & & & & $0.49^{* *}$ \\
\hline$\leq 20$ years & 64 & 40.6 & 1 & & & 1 & & \\
\hline 20-35 years & 264 & 54.5 & 1.3 & $0.9-2.0$ & & 1.2 & $0.6-2.2$ & 0.62 \\
\hline$\geq 35$ years & 39 & 56.4 & 1.4 & $0.8-2.4$ & & 1.2 & $0.5-2.9$ & 0.67 \\
\hline \multicolumn{9}{|l|}{ Parity } \\
\hline Primiparous & 165 & 49.7 & 1 & & & & & \\
\hline Multiparous & 199 & 54.3 & 1.1 & $0.8-1.5$ & 0.53 & & & \\
\hline \multicolumn{9}{|l|}{ Employment status } \\
\hline Does not work & 325 & 54.8 & 1 & & & & & \\
\hline Works & 42 & 35.7 & 0.9 & $0.8-1.1$ & 0.27 & & & \\
\hline \multicolumn{9}{|l|}{ Education level } \\
\hline Up to 8 years & 74 & 51.4 & 1 & & & & & \\
\hline 8 to 11 years & 230 & 52.6 & 1.0 & $0.7-1.5$ & & & & \\
\hline$>11$ years & 53 & 52.8 & 1.0 & $0.6-1.7$ & & & & \\
\hline
\end{tabular}

Note: ${ }^{*}$ Exclusive breastfeeding; ${ }^{* *}$ Linear trend $p$; In bold: $p<0.20$. 
$35.0 \%$ received at least one savory meal between ages 6 and 6.9 months. Thirty-nine percent of the children aged 8 to 11.9 months were given foods prepared for the family. The high consumption of high-iron foods was surprising. On the other hand, more than three-fourths of the children were given at least one unhealthy meal in the 24 hours that preceded the interview, namely cookies/biscuits or chips (63.7\%), foods with added sugar (40.4\%), drink mixes (22.4\%), coffee $(8.2 \%)$, and soda (7.1\%).
Table 3 shows the proportions of exclusively breastfed children aged less than six months, the respective Prevalence Ratios $(P R)$, and crude and adjusted $95 \% \mathrm{Cl}$ by maternal and child characteristics. In the crude analysis, female infants, infants delivered vaginally, infants who were breastfed in the first hour of life, multiparous mothers, mothers with more education, mothers who were followed at SUS, and mothers who did not work away from home had $P R$ higher than 1 , but $p>20$ kept them out of the multiple model.

Table 4. Proportion of children aged 6 to 8.9 months given Complementary Foods (fruits + savory meal) and the respective crude and adjusted Prevalence Ratios and 95\% Confidence Intervals $(95 \% \mathrm{Cl}$ ) by maternal and child characteristics. Registro (SP), 2011.

\begin{tabular}{|c|c|c|c|c|c|c|c|c|}
\hline \multirow{2}{*}{ Variables } & \multicolumn{2}{|c|}{$\mathrm{CF}^{*}$} & \multicolumn{3}{|c|}{ Crude $P R$} & \multicolumn{3}{|c|}{ Adjusted $P R$} \\
\hline & $\mathrm{n}$ & $\%$ & $P R$ & $95 \% \mathrm{Cl}$ & $p$ & $P R$ & $95 \% \mathrm{Cl}$ & $p$ \\
\hline \multicolumn{9}{|l|}{ Gender } \\
\hline Male & 71 & 63.4 & 1.0 & & & & & \\
\hline Female & 74 & 60.8 & 0.9 & $0.6-1.4$ & 0.84 & & & \\
\hline \multicolumn{9}{|l|}{ Low weight } \\
\hline Yes & 9 & 55.6 & 1.0 & & & & & \\
\hline No & 128 & 64.1 & 1.1 & $0.5-2.8$ & 0.76 & & & \\
\hline \multicolumn{9}{|l|}{ Bottle } \\
\hline No & 39 & 51.2 & 1.0 & & & & & \\
\hline Yes & 103 & 66.9 & 1.3 & $0.8-2.1$ & 0.29 & & & \\
\hline \multicolumn{9}{|l|}{ Pacifier } \\
\hline Yes & 67 & 70.1 & 1.0 & & & & & \\
\hline No & 76 & 56.6 & 1.2 & $0.8-1.9$ & 0.31 & & & \\
\hline \multicolumn{9}{|l|}{ Follow-up } \\
\hline Private & 37 & 83.8 & 1.0 & & & 1.0 & & \\
\hline Unified Health Care System & 91 & 56.0 & 0.7 & $0.4-1.0$ & 0.08 & 0.8 & $0.4-1.5$ & 0.42 \\
\hline Maternal age & & & & & & & & $0.89^{* *}$ \\
\hline$\leq 20$ years & 15 & 53.3 & 1.0 & & & & & \\
\hline 20-35 years & 87 & 64.4 & 1.2 & $0.6-2.5$ & 0.62 & & & \\
\hline$\geq 35$ years & 14 & 85.7 & 1.6 & $0.7-3.9$ & 0.29 & & & \\
\hline \multicolumn{9}{|l|}{ Parity } \\
\hline Primiparous & 57 & 70.2 & 1.0 & & & & & \\
\hline Multiparous & 57 & 61.4 & 0.9 & $0.55-1.38$ & 0.564 & & & \\
\hline \multicolumn{9}{|l|}{ Work situation } \\
\hline Does not work & 40 & 85.0 & 1.0 & & & 1.0 & & \\
\hline Works & 76 & 55.2 & 0.6 & $0.4-1.0$ & 0.06 & 0.7 & $0.4-1.2$ & 0.24 \\
\hline Education level & & & & & & & & $0.07^{* *}$ \\
\hline Up to 8 years & 18 & 44.4 & 1.0 & & & 1.0 & & \\
\hline $8-11$ years & 66 & 63.6 & 1.4 & $0.7-3.0$ & 0.35 & 1.4 & $0.6-2.9$ & 0.40 \\
\hline$>11$ years & 27 & 88.9 & 1.9 & $0.9-4.4$ & 0.09 & 1.4 & $0.5-3.7$ & 0.47 \\
\hline
\end{tabular}

Note: " Complementary foods; ${ }^{* *}$ Linear trend $p ;$ In bold: $p<0.20$.

CF: Complementary Foods; PR: Prevalence Ratios. 
The variables low birth weight, exclusive breastfeeding on the first day at home, use of pacifier, and maternal age had $p<0.20$, so they were included in the multiple regression model. In the final model, the prevalence ratios for exclusive breastfeeding were significantly higher among children who were breastfed on the first day at home $(P R=2.40 ; 95 \% \mathrm{Cl}=1.42-4.06)$ and those who did not use pacifiers $(P R=1.95$; $95 \% \mathrm{Cl}=1.15-3.30)$.

Table 4 shows the proportions of children aged 6 to 8.9 months given complementary foods (fruit and savory meal) and their crude and adjusted $P R$ and $95 \% \mathrm{Cl}$ according to maternal and child characteristics. In the exploratory analyses, children more likely to receive proper complementary foods were males, children born with appropriate birth weight, children given bottles, and children not given pacifiers. Additionally, primiparous and older mothers were more likely to offer complementary foods, but these variables were not included in the final model because their $p>0.20$. The variables included in the multiple model were: follow-up at a health care facility and maternal employment status and education level, but in the final model none of the variables remained statistically associated with the outcome.

\section{DISCUSSION}

The prevalence of exclusive breastfeeding in Registro (SP) was higher than that of Brazilian capitals and Distrito Federal (41\%), of the Southeast region (39.4\%), and of the municipality of São Paulo $(39.1 \%)^{13}$. It was also higher than those of 227 municipalities that conducted the II Survey on Breastfeeding Prevalence in $2008^{14}$, but it is still far from the WHO recommendations ${ }^{2}$. Meanwhile, the prevalence of breastfeeding at the end of the first year of life was similar to that found by the II Survey on Breastfeeding Prevalence (II PPAM/2008) $)^{13}$.

An eye-catching fact is the sharp decrease in the probability of exclusive breastfeeding as the child grows older, a trend also found in the municipality of Itapira, where only $9.6 \%$ of the children aged 121 to 180 days were being exclusively breastfed ${ }^{15}$, and Campina Grande (PB), where the prevalence of exclusive breastfeeding dropped from $20.9 \%$ in the third month to $8.3 \%$ in the sixth month ${ }^{16}$.

Exclusive breastfeeding on the first day at home after hospital discharge indicated a higher likelihood that the child would be exclusively breastfed in the first six months of life, a finding also reported by other studies ${ }^{15,17}$. Another factor associated with exclusive breastfeeding was not using a pacifier, corroborating many domestic studies ${ }^{17-21}$. These findings reinforce the importance of the information provided by maternity hospitals and the Baby-Friendly Hospital Initiative, which contemplates the Ten Steps to Successful Breastfeeding and the non-use of artificial teats and/or other fluids or foods besides breast milk ${ }^{22}$. Venancio et $a / .^{23}$ and Vieira et al..$^{24}$ found that being born at a Baby-Friendly Hospital and receiving information at maternity hospitals increase the probability of exclusive breastfeeding in the first months of life.

The prevalence of breastfeeding in the first hour of life in Registro (SP) was also higher than those found by the II Survey on Breastfeeding Prevalence in Brazilian capitals and the Distrito Federal $(67.7 \%)^{13}$, by the Pesquisa Nacional de Demografia e Saúde 2006 (PNDS, National Survey about Demographics and Health) $(43.0 \%)^{25}$, and by other regional studies ${ }^{26,27}$. This finding is very important because there is evidence that this practice can reduce neonatal mortality ${ }^{28,29}$ and encourage exclusive breastfeeding ${ }^{30}$.

The complementary feeding indicators showed that only two-thirds of the mothers followed the $\mathrm{BMH}$ recommendations regarding the introduction of fruits and savory mashes after age six months. We also found inadequacies regarding the children's meal frequency and preparation. If on the one hand almost all children aged 6 to 12 months were given high-iron foods, 
on the other hand more than $70 \%$ of the children were given unhealthy foods.

Domestic studies on complementary feeding are scarce and use different indicators at different age groups, which impairs comparing the results. However, all studies found significant inadequacies: the II PPAM/2008 ${ }^{13}$ found that more than one-fourth of the children aged 6 to 9 months were not given savory foods; likewise, the PNDS/2006 25 found that $64.4 \%$ of the children aged 6 to 8 months had been given savory foods; some domestic studies also reported the early introduction of complementary foods, that is, before the child is six months old ${ }^{31-33}$.

Domestic studies on the intake of highiron foods disagree. A study conducted in the urban area of the municipality of Acrelândia in the state of Acre with 164 children found that the proportion of children aged 9 to 11 months with low iron intake was $94 \%$, while a study conducted in the fourteen poorest municipalities of the state of Paraíba with children aged 0 to 23.9 months found that $70 \%$ of the children were consuming high-iron foods ${ }^{34}$.

A prospective study in the cities of São Paulo (SP), Curitiba (PR), and Recife (PE) found early the introduction of unhealthy foods, such as packaged sweets, sandwich cookies, instant noodles, TV dinners, soda, and drink mixes ${ }^{35}$. Population-based foreign studies that assessed the food intake of American and European (German, Polish, Italian, Spanish, and Belgium) breastfeeding infants also reported the use of inappropriate foods for this age group, such as high-fat and high-sugar foods ${ }^{36-38}$.

The absence of an association between the explanatory variables and the complementary food indicator could partly be explained by the small number of children in this age group, which consists of a study limitation. Another limitation consists on the fact that the survey was conducted on a single day during the vaccination campaign, imposing restrictions on data collection.

Notwithstanding, some positive methodological aspects deserve to be pointed out, as the methods are a widely recommended and used strategy in Brazil because of their ease of use, and low cost, and the broad coverage of vaccination campaigns ${ }^{39}$. Hence, the results are representative of the population of infants aged less than one year from the municipality of Registro (SP) and can contribute to the planning of interventions that aim to increase breastfeeding practice and the use of healthy complementary foods.

The non-adherence of the municipality of Registro (SP) to the various strategies proposed by the National Food and Nutrition Policy and National Child Health Policy is a factor that should be considered when analyzing the results. Thus, among the possible interventions, we can suggest the implementation of the Baby-Friendly Hospital Initiative because of its impact on breastfeeding indicators, and the Brazil Breastfeed and Feed Strategy, resulting in the integration of the Brazil Breastfeed Network and the National Strategy for Promoting Healthy Complementary Foods (ENPACS), whose objective is to promote breastfeeding and healthy complementary foods at the primary care level ${ }^{40}$.

We also hope that the results of this study help to generate hypotheses for future studies on the theme and contribute to increase the knowledge on the profile of complementary feeding practices in our medium, given that few studies have approached the correct introduction of complementary foods in the first year of life.

\section{COLLABORATORS}

GA TAMASIA and SI VENANCIO helped to design the study, collect data, analyze, and discuss the results of the dissertation on which this article is based. SRDM SALDIVA helped to analyze the data and write the article.

\section{RE F E R E N C E S}

1. Bhutta ZA, Das JK, Rizvi A, Gaffey MF, Walker N, Horton $\mathrm{S}$, et al. Evidence-based interventions for 
improvement of maternal and child nutrition: What can be done and at what cost? Lancet. 2013; 382(9890):452-77.

2. Brasil. Ministério da Saúde. Secretaria de Atenção à Saúde. Dez passos para uma alimentação saudável: guia alimentar para crianças menores de dois anos: um guia para o profissional da saúde na atenção básica. $2^{a}$ ed. Brasília: Ministério da Saúde; 2013.

3. Venancio SI, Saldiva SRDM, Monteiro CA. Tendência secular da amamentação no Brasil. Rev Saúde Pública. 2013; 47(6):1205-8.

4. Bortolini GA, Gubert MB, Santos LMP. Consumo alimentar entre crianças brasileiras com idade de 6 a 50 meses. Cad Saúde Pública. 2010; 28(9):175971.

5. Dias MCAP, Freire LMS, Franceschini SCC. Recomendações para alimentação complementar de crianças menores de dois anos. Rev Nutr. 2010; 23(3):475-86. http://dx.doi.org/10.1590/S1415-52 732010000300015

6. World Health Organization. Global strategy for infant and young child feeding. Geneva: WHO; 2003.

7. Atlas do Desenvolvimento Humano no Brasil. Registro, SP: indicadores de desenvolvimento humano. 2013 [acesso 2014 nov 22]. Disponível em http:/ /www.atlasbrasil.org.br/2013/pt/perfil_m/registro_ sp\#idh

8. Venancio SI, Saldiva SRDM, Castro ALS, Gouveia AGC, Santana AC, Pinto JCC, et al. Projeto amamentação e municípios: a trajetória de implantação de uma estratégia para a avaliação e monitoramento das práticas de alimentação infantil no Estado de São Paulo, no período de 1998-2008. Bepa. 2010; 7(83):4-15.

9. World Health Organization. Indicators for assessing infant and young child feeding practices: Conclusions of a consensus held 6-8 November 2007. Washington (DC): WHO; 2008.

10. Ministério da Saúde. Organização Pan-Americana de Saúde. Guia alimentar para crianças menores de 2 anos. $2^{a}$ ed. Brasília: Ministério da Saúde; 2010. Série A. Normas e Manuais Técnicos.

11. Venancio SI, Escuder MML, Saldiva SRDM, Giugliani ERJ. Breastfeeding pratice in Brazilian capital cities and Federal District: Current status e advances. J Pediat. 2010; 86(4):317-24.

12. Barros AJD, Hirakata VN. Alternatives for logistic regression in cross-sectional studies: An empirical comparison of models that directly estimate the prevalence ratio. BMC Med Res Methodol. 2003; 3:21.

13. Brasil. Ministério da Saúde. Secretaria de Atenção à Saúde. II Pesquisa de prevalência de aleitamento materno nas capitais brasileiras e Distrito Federal. Brasília: Ministério da Saúde; 2009.

14. Brasil. Ministério da Saúde. Secretaria de Atenção à Saúde. Pesquisa de prevalência de aleitamento materno em municípios brasileiros. Brasília: Ministério da Saúde; 2010.

15. Audi CAF, Correa MAS, Latorre MRDO. Alimentos complementares e fatores associados ao aleitamento materno e ao aleitamento materno exclusivo em lactentes até 12 meses de vida em Itapira, São Paulo, 1999. Rev Bras Saúde Matern Infant. 2003; 3(1):85-93.

16. Barros VO, Cardoso MAA, Carvalho DF, Gomes MMR, Ferraz NV, Medeiros CCM. Aleitamento materno e fatores associados ao desmame precoce em crianças atendidas no programa de saúde da família. Nutrire. 2009; 34(2):101-14.

17. Souza SNDH, Migoto MT, Rossetto EG, Mello DF. Prevalência de aleitamento materno e fatores associados no município de Londrina - PR. Acta Paul Enferm. 2012; 25(1):29-35.

18. Soares ME, Giugliani ER, Braun ML, Salgado AC, Oliveira AP, Aguiar PR. Uso de chupeta e sua relação com o desmame precoce em população de crianças nascidas em Hospital Amigo da Criança. J Pediatr. 2003; 79(4):309-16.

19. Feldens CA, Vitolo MR, Rauber F, Cruz LN, Hilgert JB. Risk factors for discontinuing breastfeeding in southern Brazil: A survival analysis. Matern Child Health. 2011; 16(6):1257-65.

20. Sanches MT, Buccini GD, Gimeno SG, Rosa TE, Bonamigo AW. Fatores associados à interrupção do aleitamento materno exclusivo de lactentes nascidos com baixo peso assistidos na atenção básica. Cad Saúde Pública. 2011; 27(5):953-65.

21. França GVA, Brunken GS, Silva SM, Escuder MM, Venancio SI. Determinantes da amamentação no primeiro ano de vida em Cuiabá, Mato Grosso. Rev Saúde Pública. 2007; 41(5):711-8.

22. Venancio SI. Dificuldades para o estabelecimento da amamentação: o papel das práticas assistenciais das maternidades. J Pediatr. 2003; 79(1):1-2.

23. Venancio SI, Saldiva SRDM, Escuder MML, Giugliani ERJ. The baby-friendly hospital initiative shows positive effects on breastfeeding indicators in Brazil. J Epidemiol Comm Health. 2012; 66(10):914-8.

24. Vieira TO, Vieira GO, Oliveira NF, Mendes CMC, Giugliani ERJ, Silva LR. Duration of exclusive breastfeeding in a Brazilian population: New determinants in a cohort study. BMC Pregnancy and Childbirth. 2014; 14:175.

25. Brasil. Ministério da Saúde. Pesquisa Nacional de Demografia e Saúde da Criança e da Mulher - PNDS 2006. Brasília: Ministério da Saúde; 2009. 
26. Boccolini CS, Carvalho ML, Oliveira MIC, Leal MC, Carvalho MS. Factors that affect time between birth and first breastfeeding. Cad Saúde Pública. 2008; 24(11):2681-94.

27. D’Orsi E, Chor D, Giffin K, Ângulo-Tuesta A, Barbosa GP, Gama AS, et al. Qualidade da atenção ao parto em maternidades do Rio de Janeiro. Rev Saúde Pública. 2005; 39(4):645-54.

28. Edmond KM, Zandoh C, Quigley MA, AmengaEtego S, Owusu-Agyei S, Kirkwood BR. Delayed breastfeeding initiation increases risk of neonatal mortality. Pediatrics. 2006; 117(3):380-6.

29. Boccolini CS, Carvalho ML, Oliveira MI, PérezEscamilla R. Breastfeeding during the first hour of life and neonatal mortality. J Pediatr. 2013; 89(2):131-6.

30. Neves ACM, Moura EC, Santos W, Carvalho KMB. Factors associated with exclusive breastfeeding in the Legal Amazon and Northeast regions, Brazil, 2010. Rev Nutr. 2014; 27(1):81-95. http://dx. doi.org/10.1590/1415-52732014000100008

31. Santos CS, Lima LS, Javorski M. Fatores que interferem na transição alimentar de crianças entre cinco e oito meses: investigação em serviço de puericultura do Recife, Brasil. Rev Bras Saúde Mater Infant. 2007; 7(4):373-80.

32. Saldiva SRDM, Venancio SI, Gouveia AGC, Castro ALS, Escuder MML, Giugliani ERJ. Influência regional no consumo precoce de alimentos diferentes do leite materno em menores de seis meses residentes nas capitais brasileiras e Distrito Federal. Cad Saúde Pública. 2011; 27(11):2253-62.

33. Bortolini GA, Vitolo MR, Gubert MB, Santos LM. Early cow's milk consumption among Brazilian children: Results of a national survey. J Pediatr. 2013; 89(6):608-13.
34. Garcia MT, Granado FS, Cardoso MA. Complementary feeding and nutritional status of 6-24-month-old children in Acrelândia, Acre State, Western Brazilian Amazon. Cad Saúde Pública. 2011; 27(2):305-16.

35. Palmeira PA, Santos SMC, Vianna RPT. Prática alimentar entre crianças menores de dois anos de idade residentes em municípios do semiárido do Estado da Paraíba, Brasil. Rev Nutr. 2011; 24(4):553-63. http://dx.doi.org/10.1590/\$1415-52 732011000400004

36. Caetano MC, Ortiz TTO, Silva SGL, Souza FIS, Sarni ROS. Complementary feeding: Inappropriate practices in infants. J Pediatr. 2010; 86(3):196-201.

37. Agostoni C, Braegger C, Decsi T, Kolacek S, Koletzko B, Michaelsen KF, et al. Breastfeeding: A commentary by the ESPGHAN committee on nutrition. J Pediatr Gastroenterol Nutr. 2009; 49(1):112-25.

38. Kleiman RE, editor. Pediatric nutrition handbook. $6^{\text {th }}$ ed. Elk Grove Village (IL): American Academy of Pediatrics; 2009.

39. Santos LM, Paes-Sousa R, Silva Junior JB, Victora CG. National immunization day: A strategy to monitor health and nutrition indicators. Bull World Health Organ. 2008; 86(6):474-9.

40. Brasil. Ministério da Saúde. Portaria n 1.920/2013. Institui a estratégia nacional para promoção do aleitamento materno e alimentação complementar saudável no Sistema Único de Saúde (SUS) Estratégia Amamenta e Alimenta Brasil. Brasília: Ministério da Saúde; 2013.

Received: July 10, 2014

Final version: December 2, 2014 Approved: December 16, 2014 
